\title{
Complications and Managements of Hyperphosphatemia in Dialysis
}

\author{
Eiji Takeda, Hironori Yamamoto, Hisami Yamanaka-Okumura \\ and Yutaka Taketani \\ University of Tokushima Graduate School \\ Japan
}

\section{Introduction}

\subsection{High mortality in dialysis patients}

Dialysis patients have extraordinarily high mortality rates. Cardiac disease is the major cause of death accounting for $43 \%$ of all-cause mortality among patients receiving hemodialysis and peritoneal dialysis [Henry et al., 2002; US Renal Data System Annual Data Report Bethesta, 2005]. In previous report, patients with end-stage kidney disease (chronic kidney disease (CKD) stage 5) on dialysis, in comparison with the general population, also have a 3- to 30-fold increase in mortality, depending on the age group examined, and cardiovascular disease accounts for more than half of all deaths, with myocardial infarction, ischaemic cardiomyopathy, stroke and peripheral vascular disease making up the bulk of deaths (Foley et al., 1998). The marked excess in cardiovascular mortality in CKD, compared with the general population, is not explained by the presence of traditional Framingham risk factors, such as diabetes, smoking, hypertension and elevated cholesterol levels (Zoccali, 2000; Longenecker et al., 2002). With vascular calcification and arterial stiffness being observed in young and middle-aged dialysis patients without conventional cardiovascular risk factors (London et al., 2003), the search for non-traditional risk factors has led to increasing evidence of a multitude of factors that contribute to ectopic calcification in CKD.

\subsection{High mortality rate and hyperphosphatemia}

Inorganic phosphate (phosphate) retention, or hyperphosphatemia, has been identified as playing a major role in the progression of renal failure and in the generation of secondary hyperparathyroidism and uremic bone disease (Slatopolsky et al., 2002). Further observational data have also shown a significant association of hyperphosphatemia with increased mortality among patients who have end-stage kidney disease and are on hemodialysis (Block et al., 1998; Owen \& Lowrie, 1998; Ganesh et al., 2001). Moreover, elevated serum phosphorus has been associated with an increased risk for cardiovascular mortality and hospitalization (all-cause, cardiovascular, and fracture) among dialysis patients (Block et al., 2004). Elevated phosphorus and $\mathrm{Ca} \times \mathrm{P}$ are also independent risk factors for all-cause and cardiovascular mortality in CKD stage 5, and increased levels of parathyroid hormone may be associated with both cardiovascular disease and increased 
vascular calcification (Braun et al., 1996; Block et al., 1998; Ganesh et al., 2001; Wang et al., 2003; Young et al., 2005). Thus, phosphorus has the potential to induce vascular calcification and may be cardiotoxic (Achinger \& Ayus, 2006). Hyperphosphatemia is sometimes regarded as a distinct syndrome (Hruska et al., 2008), and its treatment should be considered preferentially and even independently of other laboratory values (Fig. 1).

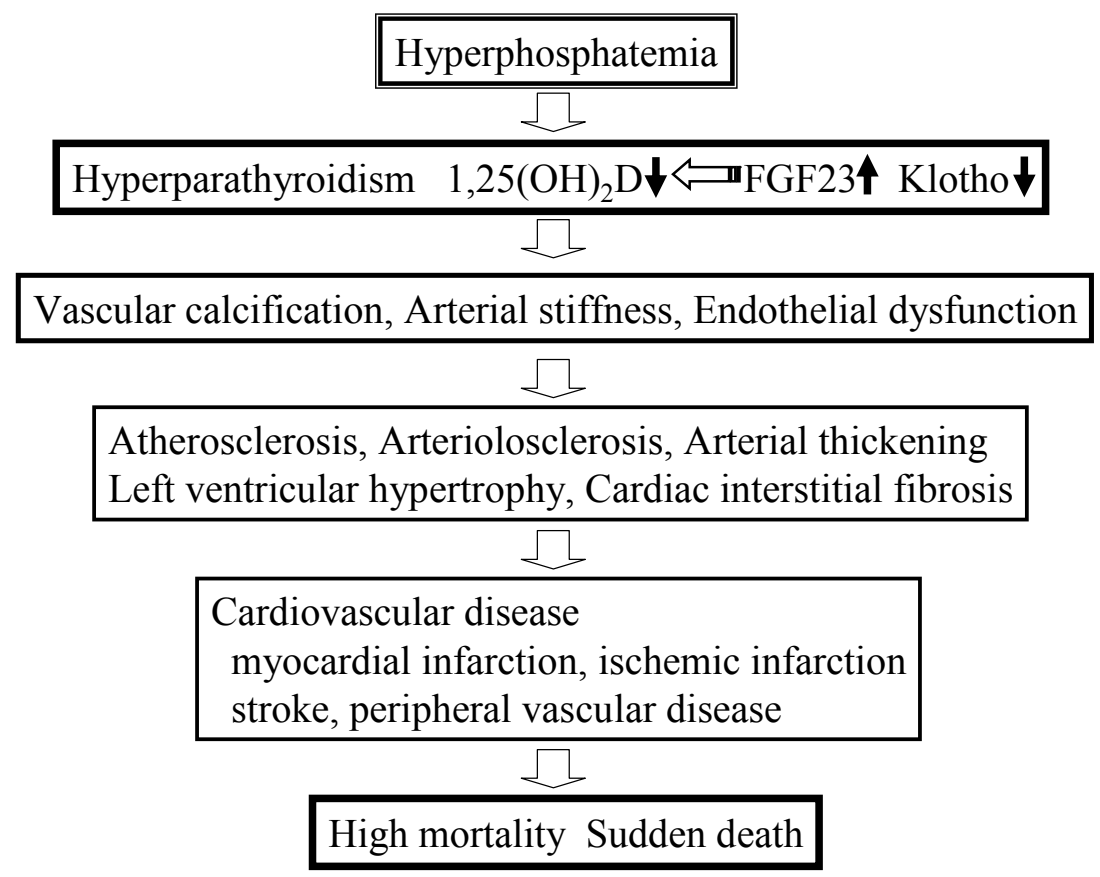

Fig. 1. Hyperphosphatemia in hemodialysis

\section{Phosphate metabolism in human}

\subsection{Phosphate metabolism in normal physiology}

Phosphorus is essential for multiple and diverse biological functions, including cellular signal transduction, mineral metabolism, and energy exchange. Although more than $80 \%$ of total body phosphorus is stored in bone and teeth, intracellular phosphorus exists in the form of organic compounds such as adenosine triphosphate and as free anions like $\mathrm{H}_{2} \mathrm{PO}_{4^{-}}$, which are commonly referred to as phosphate. Serum phosphorus primarily occurs in the form of inorganic phosphate, which is maintained within the physiological range by regulation of dietary absorption, bone formation, and renal excretion, as well as equilibration with intracellular stores (Takeda et al., 2000; Bringhurst et al., 2004; Fukagawa et al., 2004; Blumsohn, 2004).

Phosphate absorption in the renal proximal tubule and the small intestine is important for phosphate homeostasis. This is a major regulator of phosphate homeostasis and has the phosphate reabsorptive capacity to accommodate physiologic phosphate requirement. Up to $70 \%$ of filtered phosphate is reabsorbed in the proximal tubule where sodium-dependent 
phosphate transport systems in the brush-border membrane mediate the rate limiting step in the overall phosphate reabsorptive process (Murer et al, 2000; Takeda et al, 2000; Miyamoto et al, 2007; Tenenhouse, 2005; Biber et al, 2009). Three different types of sodiumdependent phosphate transporters have been identified till now, types I, II and III. The sodium-dependent phosphate transport system includes the type IIa and type IIc Nadependent phosphate cotransporters, which are localized in the apical membrane of the renal proximal tubular cells, and the type IIb Na-dependent phosphate cotransporter, which is localized in the apical membrane of the intestinal epithelial cells. The type IIa Nadependent phosphate transporter is the major determinant of plasma phosphate level and urinary phosphate excretion (Murer et al, 2000; Takeda et al, 2000; Miyamoto et al, 2007; Tenenhouse, 2005; Biber et al, 2009). This transporter is regulated by physiological stimuli, for example, type IIa transporter levels in the apical membrane are increased in response to dietary restriction of phosphate and 1,25-dihydroxy-vitamin $\mathrm{D}_{3}\left[1,25(\mathrm{OH})_{2} \mathrm{D}_{3}\right]$ and decreased in response to parathyroid hormone, or a high- phosphate diet. In addition, intestinal phosphate transport activity and type IIb Na-dependent phosphate transporter levels are upregulated by $1,25(\mathrm{OH})_{2} \mathrm{D}_{3}$ (Xu et al., 2002; Segawa et al., 2004).

In addition, fibroblast growth factor 23 (FGF23), a recently identified member of the FGF family, is involved in renal phosphate homeostasis (Yu X \& White, 2005; Yu \& White, 2005). FGF23 induces urinary phosphate excretion by suppressing the expression of type IIa and IIc Na-dependent phosphate cotransporters in the brush border of renal proximal tubules (Shimada et al., 2004; Shimada et al., 2005). It also suppresses $1,25(\mathrm{OH})_{2} \mathrm{D}$ production by inhibiting 1a-hydroxylase (CYP27B1), which converts 25-hydroxyvitamin D [25(OH)D] to $1,25(\mathrm{OH})_{2} \mathrm{D}$, and by stimulating 24-hydroxylase (CYP24), which converts $1,25(\mathrm{OH})_{2} \mathrm{D}$ to inactive metabolites in the proximal tubule of the kidney (Shimada et al., 2004; Shimada et al., 2005). Given the fact that FGF23 promotes renal phosphaturia, its secretion should be regulated by serum phosphate levels. Experimental and clinical studies showed that several days of dietary phosphate loading lead to an increase in serum FGF23 in humans (Ferrari et al, 2005; Perwad et al., 2005; Nishida et al., 2006).

\subsection{Phosphate metabolism in hemodialysis patients}

Several studies have measured circulating FGF23 levels in predialysis and dialysis patients and reported progressively elevated FGF23 levels as serum creatinine or phosphate levels increase (Larsson et al., 2003; Imanishi et al., 2004). Thus, it appears that in patients with CKD, FGF23 production increases to counteract chronic phosphate retention by promoting urinary phosphate excretion in the face of reduced nephron mass. Notably, in this setting, a previous study showed that FGF23 was a strong independent predictor of diminished $1,25(\mathrm{OH})_{2} \mathrm{D}$ levels, even after adjustment for renal function, serum phosphorus levels and 25(OH)D levels (Gutierrez et al., 2005). This finding suggests that in patients with CKD, increases in FGF23 intended to maintain neutral phosphate balance result in suppression of renal $1,25(\mathrm{OH})_{2} \mathrm{D}$ production, thereby triggering the early development of secondary hyperparathyroidism (Fig. 1).

\section{Cardiovascular disease in hemodyalysis}

\subsection{Hyperphosphatemia and cardiovascular disease}

Cardiomyopathy and ischemic heart disease including acute myocardial infarctions, which are both common conditions in dialysis patients, likely play a role in the development of 
sudden death. After percutaneous and surgical coronary revascularization, dialysis patients are still remaining at a high risk for sudden cardiac death (Furgeson, 2008). Hyperphosphatemia is a known factor contributing to the increased risk of cardiac death both in patients with end-stage renal disease and in those under renal replacement treatment with dialysis (Goodman et al., 2000). In patients with renal disease, in fact, the well-known relationship between hyperphosphataemia, secondary hyperparathyroidism, bone turnover and extra osseous calcifications has recently been followed by the recognition of a major role played by elevated serum phosphorus levels in the induction of vascular calcification, cardiac interstitial fibrosis and arterial thickening which highly increase the risk of cardiac death (Goodman et al., 2000; Block \& Port, 2000; Amann et al., 2003; Goldsmith et al., 2004; Floege \& Ketteler, 2004).

\subsection{Vascular calcification}

Phosphate is probably the predominant inducer of vascular calcification, and elevated serum levels are strongly associated with increased vascular calcification and mortality (Goodman et al., 2000). Elevated phosphate triggers a concentration-dependent precipitation of calcium in vascular smooth muscle cells, and phosphate is also a potent stimulus for the differentiation of vascular smooth muscle cells. In vitro studies demonstrate that high phosphate levels in incubation media enhance calcification with associated extracellular matrix synthesis(Jono et al., 2000). Phosphate and sodium dependent phosphate transporter seem to play a very important role in vascular smooth muscle cells mineralization. Type III sodium-dependent phosphate transporter presents two discrete subtypes, Pit-1 and Pit-2. In human vascular smooth muscle cells, Pit-1 is mainly expressed (London et al., 2000). Apatite formation by smooth muscle cells, as a response to increased phosphate levels, is fully inhibited by phosphonoformic acid (PFA), a sodium dependent phosphate transporter inhibitor, a finding supporting the notion that vascular calcification is an active rather than passive cellular process (Giachelli et al., 2001; Ketteler et al., 2003).

Hyperphosphataemia induces osteocalcin and Cbfa-1 in vascular smooth muscle cells and promotes vascular calcification. Animals deficient in Cbfa- 1 fail to mineralize bone(Komori et al., 1997), and there is also increased expression of Cbfa- 1 when vascular smooth muscle cells are incubated in uremic serum compared with pooled human serum (Moe et al., 2003). There is now considerable evidence that hyperphosphataemia regulates several signalling pathways of cell functions. Of great interest is the recent identification of a novel phosphateregulating gene, klotho (Kuro-o et al., 1997; Yoshida et al., 2002), which in mice is involved in the development of a syndrome resembling human ageing. The klotho mutant mice show abnormal calcium phosphate vitamin D metabolism and develop hyperphosphataemia and vascular calcification (Kuro-o et al., 1997; Yoshida et al., 2002). Hyperphosphataemia also down-regulates klotho gene expression (Fig. 1).

\subsection{Endothelial dysfunction}

Endothelial dysfunction is the principal cause of atherosclerosis resulting in cardio vascular disease (Ross, 1999). High phosphate loading on endothelial cells inhibited nitrogen oxide (NO) production through increased reactive oxygen species (ROS) production and endothelial NO syntase (eNOS) inactivation via conventional protein kinase C, resulting in impaired endothelium-dependent vasodilation (Shuto et al., 2009). Furthermore, dietary phosphate loading can deteriorate flow-mediated vasodilation in healthy men, suggesting 
that dietary phosphate loading or elevation of serum phosphorus level may be a risk factor for cardiovascular disease in healthy persons as well as CKD patients (Takeda et al., 2006; Shuto et al., 2009). Di Marco et al. also reported that high phosphate loading increased ROS production via phosphate influx and induced apoptosis in endothelial cells (Di Marco et al., 2008). Association of serum phosphorus level and vascular dysfunction has been well investigated, because fasting serum phosphorus level could not increase in healthy persons, even if dietary phosphate was overloaded. However, postprandial phosphorus elevation was associated with \%FMD in young healthy men (Shuto et al., 2009). Thus, dietary phosphate loading can cause endothelial dysfunction within a short time. Oxidative stress and decreased NO production in endothelial cells are possible mechanisms for the impaired endothelial function mediated by phosphate loading (Fig. 2).

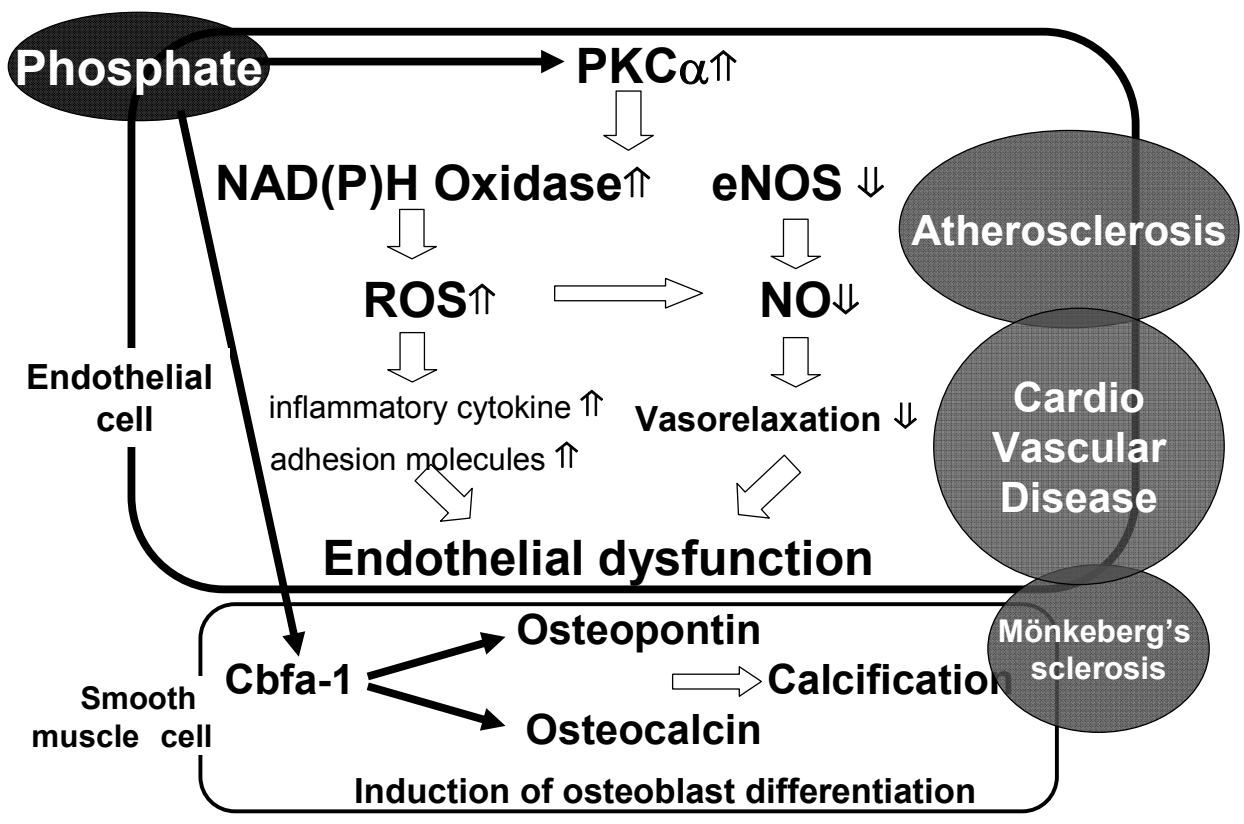

Fig. 2. Dual pathways for vascular dysfunction caused by hyperphosphatemia

\subsection{Arterial stiffness}

Arterial disease observed in end-stage kidney disease patients is characterized by extensive intimal as well as medial calcification. Histological changes in coronary arteries from dialysis patients, compared with age matched controls, reveal a similar magnitude of atherosclerotic plaque burden and intimal thickness but markedly increased medial calcification (arteriolosclerosis) (Schwarz et al., 2000). Medial calcification has been shown to affect vascular elasticity and leads to increased arterial wall stiffness of large capacity, elastic-type arteries like the aorta and the common carotid artery, increased pulse pressure 
and decreased perfusion of coronary arteries during diastole (Blacher et al., 1998; London, 2003; Speer \& Giachelli, 2004). Recent studies also demonstrated that elevated FGF23 levels were associated with arterial stiffness, increased left ventricular mass index and increased prevalence of left ventricular hypertrophy in patients with CKD (Hsu \& Wu, 2009; Mirza et al., 2009; Gutierrez et al., 2009).

\section{Management of hyperphosphatemia in hemodialysis patients}

\subsection{Target of management}

As elevated serum phosphorus and calcium levels are associated with vascular calcification and cardiovascular mortality in CKD, priority should be given to normalization of these parameters. It is generally accepted that adequate control of serum phosphorus remains a cornerstone in the clinical management of patients with CKD not only to attenuate the progression of secondary hyperparathyroidism but also possibly to reduce the risk for vascular calcification and cardiovascular mortality. A Ca $\times \mathrm{P}$ more $\tan 72 \mathrm{mg}^{2} / \mathrm{dl}^{2}$ is associated with a significant increase in the relative risk $(R R)$ of mortality $(R R=1.34)$ compared with Ca $\times$ P less than $50 \mathrm{mg}^{2} / \mathrm{dl}^{2}$ (Cozzolino et al., 2001). In a study in patients on hemodialysis, those who did not experience valvular calcification had maintained $\mathrm{Ca} \times \mathrm{P}$ at an average of $51 \mathrm{mg}^{2} / \mathrm{dl}^{2}$ in the 6 months prior to the study, while those who did experience valvular calcification had an average Ca x P of $60 \mathrm{mg}^{2} / \mathrm{dl}^{2}$ (Ribeiro et al., 1998). The target of treatment should be to maintain serum phosphorus level less than $5 \mathrm{mg} / \mathrm{dl}$ with serum calcium level less than $10 \mathrm{mg} / \mathrm{dl}$ to prevent cardio vascular consequences. This will allow the maintenance of Ca $\times$ P less than $50 \mathrm{mg}^{2} / \mathrm{dl}^{2}$, a level which available evidence has so far shown not to promote calcification or increase mortality (Ribeiro et al., 1998).

High FGF23 levels are more strongly associated with kidney disease progression, left ventricular hypertrophy, vascular disease, and mortality than serum phosphorus levels, and were most predictive of adverse events in patients with normal serum phosphorus (Thadhani et al., 2008; Oliveira et al., 2010). Dietary phosphate binders can lower FGF23 in CKD (Oliveira et al., 2010). Management of hyperphosphatemia relies on dietary restriction, the use of phosphate binders and dialysis.

\subsection{Dietary restriction of phosphate intake}

The average diet in North America and Europe contains approximately 1,000 to 1,500 mg of phosphorus per day (Willett \& Buzzard, 1998). Dietary approach to phosphate retention in advanced renal failure patients, dietary approach to phosphate reduction is an important step in the treatment of hyperphosphatemia. The level of expression of klotho mRNA was greatly reduced in the kidneys of all chronic renal failure patients. Dietary phosphate restriction induced klotho expression, which enhances the beneficial effect of phosphate restriction in patients with chronic renal failure and or on hemodialysis. However, dietary restriction cannot considerably reduce the level of phosphate retention. As dialysis patients tend to need higher levels of protein due to the losses via dialysis, tight restriction on phosphate is difficult without compromising a patient's nutritional status. Because most dietary phosphate is contained in protein-rich foods, there is some concern about excessive protein restriction. In fact, the minimum amount of protein of $1.2 \mathrm{~g} / \mathrm{kg}$ body weight/day, recommended to prevent malnutrition makes planning a diet with less than $1 \mathrm{~g}$ of phosphorus impossible (Kopple, 2001; Eknoyan et al., 2003). Recommendations that call for 1.0 to $1.2 \mathrm{~g} / \mathrm{kg} /$ day protein will usually obligate a phosphorus intake of 800 to 1,400 
mg/day. Net phosphorus absorption averages $60 \%$ to $70 \%$ of intake (Delmez \& Slatopolsky, 1992; Sheikh et al., 1989), however, this percentage can rise as high as $86 \%$ of ingested phosphate with calcitriol use and decrease to $30 \%$ to $40 \%$ of ingested phosphate with optimal binder usage.(Sheikh et al., 1989; Delmez \& Slatopolsky, 1992).

Other foods that are high in phosphate are processed foods such as processed meats which have phosphate based additives to improve the consistency and appearance of the food. Since 1990, intake of phosphate from additives has doubled and has been 1,000 $\mathrm{mg}$ in USA (Calvo \& Park, 1996). This is the amount that some renal patients are advised for the whole day from all food groups (James \& Jackson, 2002). As people are becoming more reliant on processed and packaged meals due to convenience, phosphate from these sources needs to be considered when advising on diet. Fresh meat is considered suitable for someone following a phosphate restriction, however processed foods may in fact be providing much more phosphate than realised (Sullivan et al., 2007). Beverages such as sodas, juices and sport drinks also contain phosphate additives (Murphy-Gutekunst, 2007). It has been estimated that for a person on hemodialysis the average phosphate removal per day is 300 mg (Vaithilingham et al., 2004). This leaves the patient with a positive balance for phosphate.

\subsection{Hemodialysis}

The clearance of phosphate varies among the different modalities of dialysis. Ideally, adequate dialysis in any form would remove adequate amounts of all uremic toxins, including phosphate. Unfortunately, conventional thrice-weekly hemodialysis (4 h duration) removes approximately $900 \mathrm{mg}$ of phosphorus each treatment (an average of only 300 $\mathrm{mg}$ /day) (Gotch et al., 2003). Increasing the dosage of dialysis, preferably to lengthy three times per week dialysis, hemodiafiltration, or, even better, daily/nightly dialysis may prevent phosphorus retention and even require no dietary phosphate restriction or the withdrawal of phosphate binders (Maduell et al., 2003; Benaroia et al., 2008). However, regular dialysis treatment is not able to remove all the phosphorus ingested with a diet containing protein of $1.0-1.2 \mathrm{~g} / \mathrm{kg} /$ day (Mallick \& Gokal, 1999).

\subsection{Phosphate binders}

Isakova et al analyzed a prospective cohort study of 10,044 incident hemodialysis patients at Fresenius Medical Care facilities in 2004 and 2005 comparing 1-year all-cause mortality among patients who were treated with phosphate binders (Isakova et al., 2009). In an intention-to-treat analysis, they compared patients who began treatment with any phosphate binder during the first 90 days after initiating hemodialysis, with those who remained untreated during that period. Treatment with phosphate binders was independently associated with decreased mortality compared with no treatment. In the unmatched cohort, the phosphate binder-treated group had a relative risk reduction of $42 \%$, while in the intention-to-treat and as-treated analyses, the magnitude of the survival benefit ranged between $18 \%$ and $30 \%$ in multivariate models. The association between use of phosphorus binders and survival was observed within each quartile of baseline serum phosphorus except the lowest. Results from human data suggest that lowering of phosphorus levels by intake of phosphate binders will substantially reduce serum FGF-23 levels (Koiwa et al., 2005; Pande et al., 2006). In this prospective observational study, treatment with phosphate binders was associated with a reduced 1-year mortality among incident hemodialysis patients (Isakova et al., 2009). 
Sevelamer hydrochloride and lanthanum carbonate are a phosphate binders containing neither calcium nor aluminium, and are useful in those being administered concurrent vitamin $\mathrm{D}$ to reduce the potential for hypercalcemia. Attenuation in the progression of coronary artery calcification, after 6 and 12 months, was shown in hemodialysis patients treated with sevelamer, with reduced serum calcium, compared with patients on calcium carbonate (Chertow et al., 2002). A more recent randomized study of 114 incident hemodialysis patients demonstrated a survival advantage for patients on sevelamer compared with calcium carbonate after 18-month follow up (Block et al., 2007). A further beneficial effect of sevelamer has been proved on markers of coronary artery and aortic calcification compared with calcium based phosphate binders (Chertow et al., 2002). The attenuation of vascular and, in particular, coronary calcifications compared with calciumbased phosphate binders in end-stage kidney disease patients under dialysis has been studied by electron beam computed tomography (Raggi, 2002; Raggi, 2004). High doses of sevelamer (3.2-8 g/day) are necessary to bring hyperphosphatemia back to target level, and the number of pills per day (about $8 \times 800 \mathrm{mg}$ tablets) may certainly be a conditioning factor for the patient's compliance (Chertow et al., 2002).

Patients with end-stage kidney disease treated with lanthanum carbonate up to 2.5-3.8 $\mathrm{g} /$ day for up to 2 years have been reported to obtain effective reduction of serum phosphorus level (Finn, 2006). Lanthanum-carbonate-treated patients have, also been shown to reach a significantly reduced calcium/phosphate product and parathyroid hormone level compared with the placebo (Joy \& Finn, 2009). Lanthanum carbonate, therefore, is an effective, at least as effective as calcium carbonate, well-tolerated phosphate binder (Hutchison, 2004; Hutchison et al., 2006). However, despite the very encouraging results, further studies involving larger numbers of patients are needed to definitively establish the long-term safety of lanthanum regarding tissue deposition, as well as its efficacy on vascular calcifications or outcomes in treated patients, which also need to be confirmed in the long term.

\subsection{Combination in treatment}

A multiple-factor approach can be used to reduce serum phosphate including reduced phosphorus intake in the diet, using phosphate binders efficiently and avoidance of under- dialysis. The patient's diet should be high in nutrition but with the lowest possible phosphorus content. Since dietary control of phosphorus intake and dialysis removal are usually not sufficient, phosphate binders are usually needed as adjuvants to increase fecal excretion (Bover et al; 2005). For an optimal protein diet of 1-1.2 g/ kg/day, the phosphorus intake was 778-1,444 mg/day and 5,500-10,000 mg/week. Dialysis has limited ability for phosphate control, although phosphate removal by hemodialysis is very much a time-dependent process. The amount of phosphorus removed by hemodialysis, extrapolated to an average week, is $250-300 \mathrm{mg} /$ day. The introduction of non-calciumbased phosphate binders has enabled a reduction in the total phosphate load and provides a useful tool in the prevention of vascular calcification in CKD. The use of phosphate binders may decrease the phosphorus absorbed from the diet to $40 \%$ (Llach \& Bover, 2000). In these circumstances, $320 \mathrm{mg}$ of phosphorus and $21 \mathrm{~g}$ of protein $(0.3-0.35 \mathrm{~g}$ of protein $/ \mathrm{kg} /$ day) intake should be the critical value above which a positive balance of phosphate may occur (Fig. 3). 


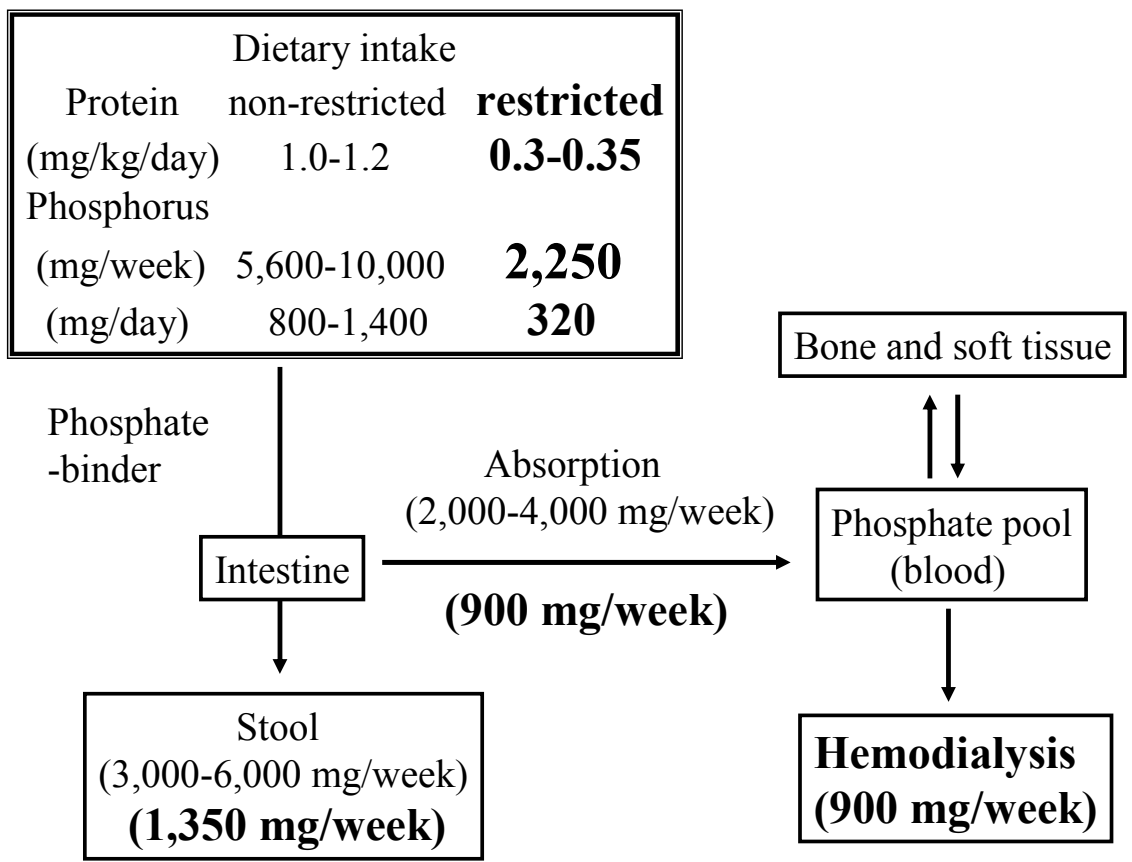

Fig. 3. Phosphate balance in hemodialysis patient

Those in restricted protein and phosphate intake are shown in bold.

Successful control of phosphate is one of the key aspects in the management of dialysis patients (Rodriguez-Benot et al., 2005; Young et al., 2004, Young et al., 2005), However, numerous studies have revealed the difficulty in achieving phosphorus targets less than 5.5 mg/dl (Arenas et al., 2006; Lorenzo et al., 2006: Wei et al., 2006), despite the wide variety of drugs available for its treatment (Joy \& Finn, 2003; Sprague, 2007; Arenas et al., 2008). Both endothelial dysfunction and medial calcification are closely associated with development of cardiovascular disease. It is well known that long-term exposure to phosphate, generally observed in end-stage renal failure patients, can mediate vascular calcification (Jono et al., 2000; Giachelli, 2003). Dietary high phosphate loading can be involved in the postprandial elevation of serum phosphorus level, and this short-term exposure to phosphate was enough to decrease endothelium-dependent vasodilation.

\section{Conclusion}

The goals of therapy have been to reduce phosphorus intake with low protein diet and phosphate binders. Since low protein diet is thought to be induce malnutrition, it is thought that strict adherence to a low protein diet is not practical. A diet rich in proteins is usually also rich in phosphorus. However, proteins with very different phosphorus contents can provide equivalent nutritional value, as can be seen from the difference in phosphorus content between meat, cheese, and eggs. Egg white is an excellent example of food with a high level of protein but low phosphorus content. Moe et al. demonstrates the importance of 
the protein source of phosphate in overall mineral metabolism after only 7 days of controlled diets. Despite equivalent protein and phosphorus concentrations in the diets, subjects had lower serum phosphorus levels, a trend toward decreased urine 24-hour phosphorus excretion, and significantly decreased FGF23 levels in the vegetarian diet compared with the meat-based diet (Moe et al., 2011).

Lafage et al. (Lafage et al., 1992) used a very low protein diet $(0.3 \mathrm{~g} / \mathrm{kg} / \mathrm{d})$ supplemented with amino acids and ketoanalogues and with only $1 \mathrm{~g}$ of calcium carbonate and 1,000 IU of vitamin $\mathrm{D}_{2}$ in 17 patients with advanced renal failure. They have shown not only a beneficial effect related to the control of hyperphosphatemia on the biologic and histologic parameters of hyperparathyroidism but also a correction of acidosis, which resulted in the disappearance of the osteomalacic component. Thus, dietary control often considered to be of minor importance, is actually one of the major keys to success in the management of hyperphosphataemia.

\section{Acknowledgements}

The work described in this publication was supported by Grants-in-Aid for Scientific Research from the Ministry of Education, Culture, Sports, Science and Technology in Japan (to ET, HY, and YT).

\section{References}

Achinger SG, Ayus JC. (2006) Left ventricular hypertrophy: is hyperphosphatemia among dialysis patients a risk factor? J Am Soc Nephrol 17(12 suppl 3): S255-S261.

Amann K, Törnig J, Kugel B, Gross ML, Tyralla K, El-Shakmak A, Szabo A, Ritz E. (2003) Hyperphosphatemia aggravates cardiac fibrosis and microvascular disease in experimental uremia. Kidney Int 63: 1296-1301.

Arenas MD, Alvarez-Ude F, Gil MT, Soriano A, Egea JJ, Millán I, Amoedo ML, Muray S, Carretón MA. (2006) Application of NKFK/DOQI clinical practice guidelines for bone metabolism and disease: changes of clinical practices and their effects on outcomes and quality standards in three haemodialysis units. Nephrol Dial Transplant. 21: 1663-1668.

Arenas MD, Malek T, Gil MT, Moledous A, Nunez C, Alvarez-Ude F. (2008) Use of aluminum-based phosphate-chelators in hemodialysis in the era of ultrapure water. Nefrologia. 28: 168-173.

Benaroia M, Pierratos A, Nesrallah GE. (2008) A primer for the prescription of short-daily and nocturnal hemodialysis. Hemodial Int 12: 23-29.

Biber J, Hernando N, Forster I, Murer H. (2009) Regulation of phosphate transport in proximal tubules. Pflu"gers Arch 458: 39-52.

Blacher J, Demuth K, Guerin AP, Safar ME, Moatti N, London GM, (1998) Influence of biochemical alterations on arterial stiffness in patients with end-stage renal disease. Arterioscler Thromb Vasc Biol 18: 535-541.

Block GA, Hulbert-Shearon TE, Levin NW, Port FK. (1998) Association of serum phosphorus and calcium $x$ phosphate product with mortality risk in chronic hemodialysis patients: A national study. Am J Kidney Dis 31: 607-617. 
Block GA, Port FK. (2000) Re-evaluation of risks associated with hyperphosphatemia and hyperparathyroidism in dialysis patients: recommendations for a change in management. Am J Kidney Dis 35: 1226-1237.

Block GA, Klassen PS, Lazarus JM, Ofsthun N, Lowrie EG, Chertow GM. (2004) Mineral metabolism, mortality, and morbidity in maintenance hemodialysis. J Am Soc Nephrol 15: 2208-2218.

Block GA, Raggi P, Bellasi A, Kooienga L, Spiegel DM. (2007) Mortality effect of coronary calcification and phosphate binder choice in incident hemodialysis patients. Kidney Int. 71: 438-441.

Blumsohn A. (2004) What have we learnt about the regulation of phosphate metabolism? Curr Opin Nephrol Hypertens. 13: 397- 401.

Bover J, Ortiz-Herbener F, Ballarín J, Andrés E, Barceló P. (2005) New therapy strategies in secondary hyperparathyroidism on dialysis (I): new concepts, new treatments. Nefrologia. 25 Suppl 2: 100-108.

Braun J, Oldendorf M, Moshage W, Heidler R, Zeitler E, Luft FC. (1996) Electron beam computed tomography in the evaluation of cardiac calcification in chronic dialysis patients. Am. J. Kidney Dis. 27: 394-401.

Bringhurst FR, Demay BM, Krane SM, Kronenberg HM. (2004) Bone and mineral metabolism in health and disease. In: Kasper DL, Braunwald E, Fauci AS, Hauser SL, Longo DL, Jameson L, Isselbacher KJ, eds. Harrison's Principles of Internal Medicine. New York, NY: McGraw-Hill.

Calvo \& Park 1996. Calvo MS, Park YK. (1996).Changing phosphorus content of the U.S. diet: potential for adverse effects on bone. J Nutr. 126(4 Suppl):1168S-1180S.

Chertow GM, Burke SK, Raggi P. (2002) Sevelamer attenuates the progression of coronary and aortic calcification in hemodialysis patients. Kidney Int. 62: 245-52.

Cozzolino M, Dusso AS, Slatopolsky D. (2001) Role of calciumphosphate product and boneassociated proteins on vascular calcification in renal failure. J Am Soc Nephrol 12: 2511-2516.

Delmez JA, Slatopolsky E. (1992) Hyperphosphatemia: its consequences and treatment in patients with chronic renal disease. Am J Kidney Dis. 19(4):303-317.

Di Marco GS, Hausberg M, Hillebrand U, Rustemeyer P, Wittkowski W, Lang D, Pavensta"dt H. (2008) Increased inorganic phosphate induces human endothelial cell apoptosis in vitro. Am J Physiol Renal Physiol 294: F1381-1387.

Eknoyan G, Levin A, Levin NW. National Kidney Foundation. (2003) Bone metabolism and disease in chronic kidney disease. Am J Kidney Dis 42 [Suppl 3]: S1-S201

Ferrari SL, Bonjour JP, Rizzoli R. (2005) Fibroblast growth factor-23 relationship to dietary phosphate and renal phosphate handling in healthy young men. J Clin Endocrinol Metab. 90: 1519-1524.

Finn WF. SPD 405-307 Lanthanum Study Group. (2006) Lanthanum carbonate versus standard therapy for the treatment of hyperphosphatemia: safety and efficacy in chronic maintenance hemodialysis patients. Clin Nephrol 65(3): 191-202.

Floege J, Ketteler M. (2004) Vascular calcification in patients with endstage renal disease. Nephrol Dial Transplant. 19 [Suppl 5]: V59-V66.

Foley RN, Parfrey PS, Sarnak MJ. (1998) Clinical epidemiology of cardiovascular disease in chronic renal disease. Am. J. Kidney Dis. 32: S112-19. 
Fukagawa M, Kurokawa K, Papadakis MA. (2004) Fluid and electrolyte disorders. In: Tierney LM, McPhee SJ, Papadakis MA, eds. Current Medical Diagnosis and Treatment 2005. New York, NY: McGraw-Hill/Appleton \& Lange; 837-867.

Furgeson SB. (2008) Chonchol: Beta-blockade in chronic dialysis patients. Semin Dial 21: 4348.

Ganesh SK, Stack AG, Levin NW, Hulbert-Shearon T, Port FK. (2001) Association of elevated serum $\mathrm{PO}(4), \mathrm{Ca} \times \mathrm{PO}(4)$ product, and parathyroid hormone with cardiac mortality risk in chronic hemodialysis patients. J Am Soc Nephrol 12: 2131-2138.

Giachelli SM, Jono S, Mori K, Morii H, (2001) Vascular calcification and inorganic phosphate. Am J Kidney Dis 38: S34-37.

Giachelli CM. (2003) Vascular calcification: In vitro evidence for the role of inorganic phosphate. J Am Soc Nephrol 14: S300-S304.

Goldsmith D, Ritz E, Covic A. (2004) Vascular calcification: a stiff challenge for the nephrologist. Kidney Int 66: 1315-1333

Goodman WG, Goldin J, Kuizon BD, Yoon C, Gales B, Sider D, Wang Y, Chung J, Emerick A, Greaser L, Elashoff RM, Salusky IB. (2000) Coronary-artery calcification in young adults with end-stage renal disease who are undergoing dialysis. $N$ Engl J Med 342: 1478-1483

Gotch FA, Panlilio F, Sergeyeva O, Rosales L, Folden T, Kaysen G, Levin NW. (2003) A kinetic model of inorganic phosphorus mass balance in hemodialysis therapy. Blood Purif 21: 51-57.

Gutierrez O, Isakova T, Rhee E, Shah A, Holmes J, Collerone G, Jüppner H, Wolf M. (2005) Fibroblast growth factor-23 mitigates hyperphosphatemia but accentuates calcitriol deficiency in chronic kidney disease. J Am Soc Nephrol. 16: 2205-2215.

Gutiérrez OM, Mannstadt M, Isakova T, Rauh-Hain JA, Tamez H, Shah A, Smith K, Lee H, Thadhani R, Jüppner H, Wolf M. (2008) Fibroblast growth factor 23 and mortality among patients undergoing hemodialysis. N Engl J Med. 359(6): 584-592.

Gutiérrez OM, Januzzi JL, Isakova T, Laliberte K, Smith K, Collerone G, Sarwar A, Hoffmann U, Coglianese E, Christenson R, Wang TJ, deFilippi C, Wolf M. (2009) Fibroblast growth factor-23 and left ventricular hypertrophy in chronic kidney disease. Circulation. 119: 2545-2552.

Henry RM, Kostense PJ, Bos G, Dekker JM, Nijpels G, Heine RJ, Bouter LM, Stehouwer CD: (2002) Mild renal insufficiency is associated with increased cardiovascular mortality: the Hoorn Study. Kidney Int 62: 1402-1407.

Hruska KA, Mathew S, Lund R, Qiu P, Pratt R. (2008) Hyperphosphatemia of chronic kidney disease. Kidney Int 74: 148-157.

Hsu HJ, Wu MS. (2009) Fibroblast growth factor 23: a possible cause of left ventricular hypertrophy in hemodialysis patients. Am J Med Sci. 337:116-122.

Hutchison AJ. (2004) Improving phosphate-binder therapy as a way forward. Nephrol Dial Transplant 19 [Suppl 1]: i19-i24.

Hutchison AJ, Maes B, Vanwalleghem J, Asmus G, Mohamed E, Schmieder R, Backs W, Jamar R, Vosskühler A. (2006) Long-term efficacy and tolerability of lanthanum carbonate: results from a 3-year study. Nephron Clin Pract 102: c61-c71.

Imanishi Y, Inaba M, Nakatsuka K, Nagasue K, Okuno S, Yoshihara A, Miura M, Miyauchi A, Kobayashi K, Miki T, Shoji T, Ishimura E, Nishizawa Y. (2004) FGF-23 in patients with end-stage renal disease on hemodialysis. Kidney Int. 65: 1943-1946. 
Isakova T, Gutiérrez OM, Chang Y, Shah A, Tamez H, Smith K, Thadhani R, Wolf M. (2009) Phosphorus binders and survival on hemodialysis. J Am Soc Nephrol. 20: 388-396.

James G, Jackson H: European guidelines for the nutritional care of adult renal patients. (2002) EDTNA/ERCA, pp1-52.

Jono S, McKee MD, Murry CE, Shioi A, Nishizawa Y, Mori K, Morii H, Giachelli CM. (2000) Phosphate regulation of vascular smooth muscle cell calcification. Circ. Res. 87: E10-17.

Joy MS, Finn WF. (2003) Randomized, double-blind, placebocontrolled, dose-titration, Phase III study assessing the efficacy and tolerability of lanthanum carbonate: a new phosphate binder for the treatment of hyperphosphatemia. Am J Kidney Dis 42: 96107.

Ketteler M, Bongartz P, Westenfeld R, Wildberger JE, Mahnken AH, Böhm R, Metzger T, Wanner C, Jahnen-Dechent W, Floege J. (2003) Association of low fetuin-A (AHSG) concentrations in serum with cardiovascular mortality in patients on dialysis: a cross-sectional study. Lancet 361: 827-833.

Koiwa F, Kazama JJ, Tokumoto A, Onoda N, Kato H, Okada T, Nii-Kono T, Fukagawa M, Shigematsu T; ROD21 Clinical Research Group. (2005) Sevelamer hydrochloride and calcium bicarbonate reduce serum fibroblast growth factor 23 levels in dialysis patients. Ther Apher Dial 9: 336-339.

Komori T, Yagi H, Nomura S, Yamaguchi A, Sasaki K, Deguchi K, Shimizu Y, Bronson RT, Gao YH, Inada M, Sato M, Okamoto R, Kitamura Y, Yoshiki S, Kishimoto T. (1997) Targeted disruption of Cbfa1 results in a complete lack of bone formation owing to maturational arrest of osteoblasts. Cell. 89(5):755-764.

Kopple JD. (2001) National Kidney Foundation K/DOQI clinical practice guidelines for nutrition in chronic renal failure. Am J Kidney Dis 37 [Suppl 2]: S66-S70.

Kuro-o M, Matsumura Y, Aizawa H, Kawaguchi H, Suga T, Utsugi T, Ohyama Y, Kurabayashi M, Kaname T, Kume E, Iwasaki H, Iida A, Shiraki-Iida T, Nishikawa S, Nagai R, Nabeshima YI. (1997) Mutation of the mouse klotho gene leads to a syndrome resembling ageing. Nature 390: 45-51.

Lafage MH, Combe C, Fournier A, Aparicio M. (1992) Ketodiet, physiological calcium intake and native vitamin D improve renal osteodystrophy. Kidney Int. 42(5): 1217-1225.

Larsson T, Nisbeth U, Ljunggren O, Jüppner H, Jonsson KB. (2003) Circulating concentration of FGF-23 increases as renal function declines in patients with chronic kidney disease, but does not change in response to variation in phosphate intake in healthy volunteers. Kidney Int. 64: 2272-2279.

Llach L, Bover J. (2000) Renal osteodystriphies; in Brenner BM (ed): The Kidney. Philadelphia, Saunders, pp2103-2186.

London GM. (2000) Alterations of arterial function in end-stage renal disease. Nephron 84: 111-118.

London GM. (2003) Cardiovascular Calcifications in Uremic Patients: Clinical Impact on Cardiovascular Function. J Am Soc Nephrol 14: S305-S309.

London GM, Guérin AP, Marchais SJ, Métivier F, Pannier B, Adda H. (2003) Arterial media calcification in end-stage renal disease: Impact on all-cause and cardiovascular mortality. Nephrol. Dial. Transplant 18: 1731-1740. 
Longenecker JC, Coresh J, Powe NR Levey AS, Fink NE, Martin A, Klag MJ. (2002) Traditional cardiovascular disease risk factors in dialysis patients compared with the general population: The CHOICE Study. J. Am. Soc. Nephrol. 13: 1918-1927.

Lorenzo V, Martin-Malo A, Perez-Garcia R, Torregrosa JV, Vega N, de Francisco AL, Cases A. (2006) Prevalence, clinical correlates and therapy cost of mineral abnormalities among haemodialysis patients: a cross-sectional multicentre study. Nephrol Dial Transplant. 21: 459-465.

Maduell F, Navarro V, Torregrosa E, Rius A, Dicenta F, Cruz MC, Ferrero JA. (2003) Change from three times a week on-line hemodiafiltration to short daily on-line hemodiafiltration. Kidney Int 64: 305-313.

Mallick NP, Gokal R. (1999) Haemodialysis. Lancet 353: 737-742

Mirza MA, Larsson A, Lind L, Larsson TE. (2009) Circulating fibroblast growth factor-23 is associated with vascular dysfunction in the community. Atherosclerosis. 205: 385390.

Miyamoto K, Ito M, Tatsumi S, Kuwahata M, Segawa H. (2007) New aspect of renal phosphate reabsorption: the type IIc sodium-dependent phosphate transporter. Am J Nephrol 27: 503-515.

Miyamoto K, Segawa H, Ito M, Kuwahata M. (2004) Physiological regulation of renal sodium-dependent phosphate cotransporters. Jpn J Physiol 54: 93-102.

Moe SM, Duan D, Doehle BP, O'Neill KD, Chen NX. (2003) Uremia induces the osteoblast differentiation factor Cbfa1 in human blood vessels. Kidney Int. 63: 1003-1011.

Moe SM, Zidehsarai MP, Chambers MA, Jackman LA, Radcliffe JS, Trevino LL, Donahue SE, Asplin JR. (2010) Vegetarian compared with meat dietary protein source and phosphorus homeostasis in chronic kidney disease. Clin J Am Soc Nephrol. 6(2): 257264.

Murer H, Hernando N, Forster I, Biber J. (2000) Proximal tubular phosphate reabsorption: molecular mechanisms. Physiol Rev 80: 1373-1409.

Murphy-Gutekunst L. (2007) Hidden phosphorus: where do we go from here ? J Ren Nutr 4: e31-e36.

Nishida Y, Taketani Y, Yamanaka-Okumura H, Imamura F, Taniguchi A, Sato T, Shuto E, Nashiki K, Arai H, Yamamoto H, Takeda E. (2006) Acute effect of oral phosphate loading on serum fibroblast growth factor 23 levels in healthy men. Kidney Int. 70: 2141-2147.

Oliveira RB, Cancela AL, Graciolli FG, Dos Reis LM, Draibe SA, Cuppari L, Carvalho AB, Jorgetti V, Canziani ME, Moysés RM.. (2010) Early control of PTH and FGF23 in normophosphatemic CKD patients: a new target in CKD-MBD therapy? Clin J Am Soc Nephrol. 5(2): 286-291.

Owen WF, Lowrie EG: (1998) C-reactive protein as an outcome predictor for maintenance hemodialysis patients. Kidney Int 54: 607-617.

Pande S, Ritter CS, Rothstein M, Wiesen K, Vassiliadis J, Kumar R, Schiavi SC, Slatapolsky E, Brown AJ. (2006) FGF-23 and sFRP-4 in chronic kidney disease and post-renal transplantation. Nephron Physiol 104: 23-32.

Perwad F, Azam N, Zhang MY, Yamashita T, Tenenhouse HS, Portale AA. (2005) Dietary and serum phosphorus regulate fibroblast growth factor 23 expression and 1,25dihydroxyvitamin D metabolism in mice. Endocrinology. 146: 5358-5364. 
Raggi P. (2000) Detection and quantification of cardiovascular calcifications with electron beam tomography to estimate risk in hemodialysis patients. Clin Nephrol 54: 325333.

Raggi P. (2002) Effects of excess calcium load on the cardiovascular system measured with electron beam tomography in end-stage renal disease. Nephrol Dial Transplant 17: 332-335.

Ribeiro S, Ramos A, Brandão A, Rebelo JR, Guerra A, Resina C, Vila-Lobos A, Carvalho F, Remédio F, Ribeiro F. (1998) Cardiac valve calcification in haemodialysis patients: role of calcium-phosphate metabolism. Nephrol Dial Transplant 13: 2037-2040.

Rodriguez-Benot A, Martin-Malo A, Alvarez-Lara MA, Rodriguez M, Aljama P. (2005) Mild hyperphosphatemia and mortality in hemodialysis patients. Am J Kidney Dis. 46: 6877.

Ross R. (1999) Atherosclerosis-an inflammatory disease. N Engl J Med 340: 115-126.

Schwarz U, Buzello M, Ritz E, Stein G, Raabe G, Wiest G, Mall G, Amann K. (2000) Morphology of coronary atherosclerotic lesions in patients with end-stage renal failure. Nephrol. Dial. Transplant. 15: 218-223.

Segawa H, Kaneko I, Setsuko Y, Ito M, Kuwahata M, Inoue Y, Kato S, Miyamoto K. (2004) Intestinal Na-Pi cotransporter adaptation to dietary $\mathrm{Pi}$ content in vitamin $\mathrm{D}$ receptor null mice. Am J Physiol Renal Physiol 287: F39-F47.

Seiler S, Reichart B, Roth D, Seibert E, Fliser D, Heine GH. (2010) FGF-23 and future cardiovascular events in patients with chronic kidney disease before initiation of dialysis treatment. Nephrol Dial Transplant. 25(12): 3983-3989.

Sheikh MS, Maguire JA, Emmett M, Santa Ana CA, Nicar MJ, Schiller LR, Fordtran JS. (1989) Reduction of dietary phosphorus absorption by phosphorus binders. A theoretical, in vitro, and in vivo study. J Clin Invest. 83(1): 66-73.

Shimada T, Hasegawa H, Yamazaki Y, Muto T, Hino R, Takeuchi Y, Fujita T, Nakahara K, Fukumoto S, Yamashita T. (2004) FGF-23 is a potent regulator of vitamin D metabolism and phosphate homeostasis. J Bone Miner Res. 19: 429-435.

Shimada T, Yamazaki Y, Takahashi M, Hasegawa H, Urakawa I, Oshima T, Ono K, Kakitani M, Tomizuka K, Fujita T, Fukumoto S, Yamashita T. (2005) Vitamin D receptorindependent FGF23 actions in regulating phosphate and vitamin D metabolism. Am J Physiol Renal Physiol. 289: F1088-F1095.

Shuto E, Taketani Y, Tanaka R, Harada N, Isshiki M, Sato M, Nashiki K, Amo K, Yamamoto H, Higashi Y, Nakaya Y, Takeda E. (2009) Dietary phosphorus acutely impairs endothelial function. J Am Soc Nephrol. 20(7): 1504-1512.

Slatopolsky E, Brown A, Dusso A. (2002) Role of phosphorus in the pathogenesis of secondary hyperparathyroidism. Am J Kidney Dis 37: S54-S57.

Speer MY, Giachelli CM, (2004) Regulation of cardiovascular calcification. Cardiovascular Pathology 13: 63-70.

Sprague SM. (2007) A comparative review of the efficacy and safety of established phosphate binders: calcium, sevelamer, and lanthanum carbonate. Curr Med Res Opin. 23: 3167-3175.

Sullivan CM, Leon JB, Sehgal AR. (2007) Phosphorus-containing food additives and the accuracy of nutrient databases: implications for renal patients. J Ren Nutr. 17(5): 350-354. 
Takeda E, Taketani Y, Morita K, Tatsumi S, Katai K, Nii T, Yamamoto H, Miyamoto K. (2000) Molecular mechanisms of mammalian inorganic phosphate homeostasis. Adv Enzyme Regul 40: 285-302.

Takeda E, Taketani Y, Nashiki K, Nomoto M, Shuto E, Sawada N, Yamamoto H, Isshiki M. (2006) A novel function of phosphate-mediated intracellular signal transduction pathways. Adv Enzyme Regul 46: 154-161.

Tenenhouse HS. (2006) Regulation of phosphorus homeostasis by the type IIa $\mathrm{Na}$ /phosphate cotransporter. Annu Rev Nutr 25: 197-214.

US Renal Data System Annual Data Report Bethesta (2005) National Institutes of Health National Institute of Diabetes and Digestive and Kidney Diseases.

Vaithilingam I, Polkinghorne KR, Atkins RC, Kerr PG. (2004) Time and exercise improve phosphate removal in hemodialysis patients. Am J Kidney Dis. 43(1): 85-89.

Wang AY, Wang M, Woo J, Lam CW, Li PK, Lui SF, Sanderson JE. (2003) Cardiac valve calcification as an important predictor for all-cause mortality and cardiovascular mortality in long-term peritoneal dialysis patients: A prospective study. J. Am. Soc. Nephrol. 14: 159-168.

Wei M, Taskapan H, Esbaei K, Jassal SV, Bargman JM, Oreopoulos DG. (2006) K/DOQI guideline requirements for calcium, phosphate, calcium phosphate product, and parathyroid hormone control in dialysis patients: can we achieve them? Int Urol Nephrol. 38: 739-743.

Willett WC, Buzzard M. (1998) Nature of Variation in Diet in Nutritional Epidemiology, 2nd Ed., edited by Willett WC, New York, Oxford University Press, pp33-49.

Xu H, Bai L, Collins JF, Ghishan FK. (2002) Age-dependent regulation of rat intestinal type IIb sodium-phosphate cotransporter by 1,25-(OH2) vitamin D3. Am J Physiol Cell Physiol 282: C487-C493.

Yoshida T, Fujimori T, Nabeshima Y. (2002) Mediation of unusually high concentrations of 1,25-dihydroxyvitamin $\mathrm{D}$ in homozygous klotho mutant mice by increased expression of renal 1 alpha-hydroxylase gene. Endocrinology 143: 683-689.

Young EW, Akiba T, Albert JM, McCarthy JT, Kerr PG, Mendelssohn DC, Jadoul M. (2004) Magnitude and impact of abnormal mineral metabolism in hemodialysis patients in the Dialysis Outcomes and Practice Patterns Study (DOPPS). Am J Kidney Dis. 44(Suppl 2): 34-38.

Young EW, Albert JM, Satayathum S, Goodkin DA, Pisoni RL, Akiba T, Akizawa T, Kurokawa K, Bommer J, Piera L, Port FK. (2005) Predictors and consequences of altered mineral metabolism: The Dialysis Outcomes and Practice Patterns Study. Kidney Int. 67: 1179-1187.

Yu X, White KE. (2005) Fibroblast growth factor 23 and its receptors. Ther Apher Dial 9: 308312.

Yu X, White KE. (2005) FGF23 and disorders of phosphate homeostasis. Cytokine Growth Factor Rev 16: 221-232.

Zoccali C. (2000) Cardiovascular risk in uraemic patients - Is it fully explained by classical risk factors? Nephrol. Dial. Transplant. 15: 454-457. 


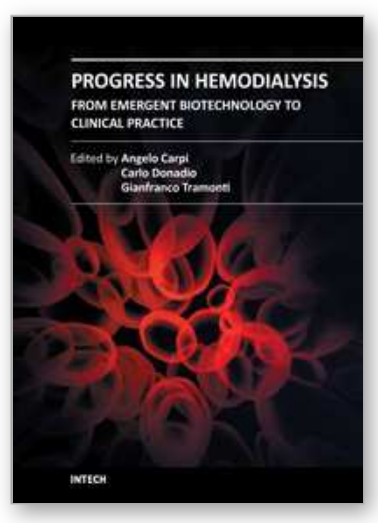

\section{Progress in Hemodialysis - From Emergent Biotechnology to Clinical Practice}

Edited by Prof. Angelo Carpi

ISBN 978-953-307-377-4

Hard cover, 444 pages

Publisher InTech

Published online 07, November, 2011

Published in print edition November, 2011

Hemodialysis (HD) represents the first successful long-term substitutive therapy with an artificial organ for severe failure of a vital organ. Because HD was started many decades ago, a book on HD may not appear to be up-to-date. Indeed, HD covers many basic and clinical aspects and this book reflects the rapid expansion of new and controversial aspects either in the biotechnological or in the clinical field. This book revises new technologies and therapeutic options to improve dialysis treatment of uremic patients. This book consists of three parts: modeling, methods and technique, prognosis and complications.

\section{How to reference}

In order to correctly reference this scholarly work, feel free to copy and paste the following:

Eiji Takeda, Hironori Yamamoto, Hisami Yamanaka-Okumura and Yutaka Taketani (2011). Complications and Managements of Hyperphosphatemia in Dialysis, Progress in Hemodialysis - From Emergent Biotechnology to Clinical Practice, Prof. Angelo Carpi (Ed.), ISBN: 978-953-307-377-4, InTech, Available from: http://www.intechopen.com/books/progress-in-hemodialysis-from-emergent-biotechnology-to-clinicalpractice/complications-and-managements-of-hyperphosphatemia-in-dialysis

\section{INTECH}

open science | open minds

\section{InTech Europe}

University Campus STeP Ri

Slavka Krautzeka 83/A

51000 Rijeka, Croatia

Phone: +385 (51) 770447

Fax: +385 (51) 686166

www.intechopen.com

\section{InTech China}

Unit 405, Office Block, Hotel Equatorial Shanghai

No.65, Yan An Road (West), Shanghai, 200040, China

中国上海市延安西路65号上海国际贵都大饭店办公楼405单元

Phone: +86-21-62489820

Fax: $+86-21-62489821$ 
(C) 2011 The Author(s). Licensee IntechOpen. This is an open access article distributed under the terms of the Creative Commons Attribution 3.0 License, which permits unrestricted use, distribution, and reproduction in any medium, provided the original work is properly cited. 